\title{
Long-Term Profitability of Volume-Based Price Momentum in Taiwan
}

\author{
Hsiao-Peng $\mathrm{Fu}^{1}$ \\ ${ }^{1}$ Department of Finance, Providence University, Taiwan, R.O.C. \\ Correspondence: Hsiao-Peng Fu, Department of Finance, Providence University, 200, Section 7, Taiwan Boulevard \\ Road, Shalu District, Taichung 43301, Taiwan, R.O.C. Tel: 886-42-632-8001 Ext. 13614. E-mail: hspefu@pu.edu.tw \\ Received: December 18, 2013 \\ Accepted: January 13, $2014 \quad$ Online Published: March 30, 2014 \\ doi:10.5430/ijfr.v5n2p1 \\ URL: http://dx.doi.org/10.5430/ijfr.v5n2p1
}

\begin{abstract}
In the Taiwanese stock market, this paper discovers a significant outperformance of volume-based price momentum strategies relative to pure price momentum strategies over the holding period of 3-5 years. Specifically, hedge portfolios that are longing low-volume winners and shorting high-volume losers generate superior returns than pure price hedge portfolios of buying winners and selling losers. Moreover, the opposed strategies of buying high-volume winners and selling low-volume losers systematically underperform the pure price momentum strategies. Both results are consistent with those from US. More importantly, both outperformance and underperformance are robust to adjustment of industry effects, book-to-market ratio, and firm size. Furthermore, firm size seems to subsume a larger portion of superior and inferior performances than the other two control factors because the economic magnitude of outperformance and underperformance deteriorates more intensively when it is conditional on firm size than on the other two factors.
\end{abstract}

Keywords: emerging markets, glamour firms, price momentum, trading volume

\section{Introduction}

Prior research on trading volume literature generally accepts the notion that trading volume is proxy for liquidity; higher trading volume forecasts lower future expected returns due to better liquidity (for example, Amihud and Mendelson, 1986; Campbell, Grossman, and Wang, 1993; Conrad, Hameed, and Niden, 1994; Datar, Naik, and Rodcliffe, 1998). Recently, however, Lee and Swaminathan (2000) uncovered an association between higher-volume and high-momentum profits, contrary to the traditional negative relationship. They suggested and confirmed a new role of trading volume. Specifically, they reported that high-volume stocks behave like glamour stocks (that is, better operating performance, lower book-to-market ratios, higher analyst coverage, higher future earnings forecasts and higher past long-term stock returns,). Therefore, trading volume becomes a variable for distinguishing between value and glamour stocks, i.e. high (low) volume is connected with glamour (value) stocks. Furthermore, they found the relationship between trading volume and expect returns differs for winning and losing stocks. They therefore developed momentum life-cycle (MLC) hypotheses, which predict that high- (low-)volume winners (losers) experience faster return reversals, whereas low- (high-)volume winners (losers) experience longer return continuation. In accordance with the predictions, they found investment strategies of buying low-(high-)volume winners and selling high- (low-)volume losers generate higher (lower) profitability than pure price momentum strategies based solely on past prices. They named the better (worse) performance strategies as early-(late-)stage price momentum strategies. Note that although both the early and late stages experience return reversals, the latter experiences them sooner than the former. This is why it is called the later stage of price momentum phenomenon because the price momentum will reach an end sooner for the late stage.

The Taiwanese stock market is well known for its high trading volume. In 2011, the Taiwanese market was the world's 16th largest in terms of trading value. As a result, the market is a good setting for studying trading volume. With respect to price momentum, prior research prevalently uncovered weak price momentum in this market (see Chui, Titman, and Wei, 2003; Hameed and Kusnadi, 2002; Griffin, Ji, and Martin, 2005; Fu and Wood, 2010). Therefore, this analysis provides out-of-sample tests for the MLC hypotheses in a stock market showing the absence of price momentum, contrary to the US stock markets in which strong price momentum is commonly detected (for example, Jegadeesh and Titman, 1993, 2001; Chan, Jegadeesh, and Lakonishok, 1996, 1999). Using a portfolio approach, I revealed the existence of the early- and late-stage price momentum phenomena over holding periods of 3-5 years in Taiwan, which corroborats the MLC predictions. The exclusive long-term findings are different from 
those in the US, which state that the MLC theory exists in both intermediate and long horizons. The absence of significant phenomena in the intermediate term in Taiwan may be attributed to the lack of intermediate-term price momentum. Furthermore, the significant results survive the robustness check of industry effect, book-to-market ratio and firm size.

Prior empirical results for the MLC theory in the setting of Asian countries are mixed. Ding, McInish, and Wongchoti (2008) investigated the predictions of the MLC over 2-8 weeks after formation of portfolios, which is constructed from prior one-week data. They found some extent of support in Hong Kong (which showed strongest results), Japan, Malaysia, Thailand and Singapore, but not in Korea and Taiwan. As opposed to their short-term study, I observed the intermediate- and long-term impact, i.e. over holding periods of six-month and 1-5 years. In addition, I tested the explanatory power of industry effects (in addition to size and book-to-market ratio), which is void in their research. Shawn, Dawei, and Benjamin (2013) found weak price momentum in the Philippines and equally weak improvement of hedge portfolios of price momentum conditional on trading volume. Their results are for the intermediate term, i.e. 3-12 months and did not consider the long-term effects. Hence, this study contributes to MLC research in the setting of Asian markets by offering long-horizon investigation which, to the best of my knowledge, has not been done before.

The remainder of this paper is organised as follows. Section 1 describes data and methodology. Section 2 presents the empirical findings. The final section contains the conclusion.

\section{Data and Methodology}

Unless otherwise mentioned, I have used monthly data from July 1975 to December 2003 compiled by the Taiwan Economic Journal (hereafter TEJ). Observation includes all non-financial common stocks listed on the Taiwan Stock Exchange (TWSE) over the sample period, even if the stocks were de-listed during the sample period. (Note 1) Consequently, this analysis suffers little from survivorship bias.

As in the study by Lee and Swaminathan (2000), I constructed price momentum portfolios on the basis of both prior stock returns and prior trading volume at the end of each month, where two types of portfolios are formed independently. Return (volume) portfolios of R1(V1), R2(V2) and R3(V3) are composed of the 30,40 and 30 percent of stocks having the lowest, medium and highest return (trading volume), respectively, over the past six months. As a result, nine volume-based price momentum portfolios are formed. Portfolios with the number of component stocks less than five are dropped. The trading volume is proxy by an average of monthly turnover ratio during the past six months, where the turnover ratio is estimated by the number of shares traded during each month to the number of shares outstanding at the end of the month.

The portfolios are held for six months and one (1) to five (5) years, unless otherwise mentioned. In addition, to avoid potential short-term bid-ask swing effects that are found in the US market (for example, Jegadeesh, 1990; Lehmann, 1990), one month was skipped between the ranking and the holding periods (Lee and Swaminathan, 2000). For the six-month holding period, portfolios are re-balanced each month as suggested in the study by Jegadeesh and Titman (1993). With respect to holding periods of 1-5 years, I followed th event year approach in the study by Lee and Swaminathan (2000). As in most Asian research, portfolio returns are estimated by value-weighting component stocks, because stocks in Asian markets may be smaller than those in developed markets, and thereby introduce greater microstructure issues (Chui et al., 2003). To correct for heteroskedasticity and autocorrelation, I used Newey-West standard errors.

Table 1 reports mean monthly returns and median monthly turnovers over ranking period, median firm size and median stock prices at the ranking date, and the number of observations measured in firm-months. Return in percentage is the time-series average of value-weighted portfolio returns calculated from geometric mean returns of component stocks over the six-month ranking period. Portfolio turnover is the time-series average of the median turnover ratio of component stocks over the ranking period of six months. Size, in millions of New Taiwan Dollars, for individual stocks is measured by multiplying market prices by outstanding shares. Portfolio size is the time-series average of the median size of component stocks at the ranking date. Portfolio price, in New Taiwan Dollars, is the time-series average of the median closing prices of the component stocks at the ranking date.

As can be seen from the summary statistics exhibited in Table 1, low-volume securities are associated with larger market capitalization, narrower ranking-period return difference between winners and losers, and medium stock prices. The evidence is consistent with the intuition that larger-capitalization stocks are held more heavily by institutional investors than by retail investors, and institutional investors trade less frequently than do retail investors. Moreover, the size difference provides motivation to control for firm size, among other variables, in later tests. 
Table 1. Descriptive statistics

\begin{tabular}{|l|l|c|c|c|c|c|}
\hline \multicolumn{2}{|c|}{ Portfolios } & Firm-month & Return(\%) & Turnover(\%) & Size (Mil. of NTD) & Price (NTD) \\
\hline V1(Low) & P1(Losers) & 4,620 & -2.41 & 8.38 & 7,705 & 13.23 \\
\hline & P2 & 6,367 & 0.52 & 9.07 & 8,960 & 13.45 \\
\hline & P3(Winners) & 3,633 & 3.66 & 9.02 & 12,613 & 18.05 \\
\hline V2 & P1(Losers) & 6,077 & -2.48 & 24.79 & 4,251 & 13.45 \\
\hline & P2 & 8,022 & 0.50 & 25.07 & 4,852 & 13.27 \\
\hline & P3(Winners) & 5,405 & 4.09 & 25.87 & 6,494 & 16.83 \\
\hline V3(High) & P1(Losers) & 3,923 & -2.57 & 53.88 & 4,106 & 17.27 \\
\hline & P2 & 5,115 & 0.62 & 54.38 & 4,441 & 17.97 \\
\hline & P3(Winners) & 5,582 & 4.25 & 59.14 & 5,419 & 20.06 \\
\hline
\end{tabular}

\section{Empirical Results}

\subsection{Profitability in Intermediate Term}

Table 2 summarises the time-series average of monthly profits for hedge portfolios based on various investment strategies with a ranking period of past six months and holding periods of 3-12 months. Apparently, there is no significant price momentum, reminiscent of prior weak findings for the market (for example, Chui et al., 2003; Hameed and Kusnadi, 2002; Griffin et al., 2005; Fu and Wood, 2010). In addition, adding trading volume to pure price momentum strategies appears to exploit higher (lower) profitability under the early- (late-)stage strategies of buying low-volume (high-volume) winners and selling high-volume (low-volume) losers. The asymmetric patterns indicate price continuation in the early stage and price reversal in the late stage. As a result, hedge portfolios relative to the early stage outperform those of the late stage. Directions of all the results are similar to those in the US. However, all of the return differences are not statistically significant, as shown in columns (4), (5) and (6).

Table 2. Monthly returns on hedge portfolios

\begin{tabular}{|c|c|c|c|c|c|c|c|c|c|c|c|c|}
\hline & \multirow{2}{*}{\multicolumn{2}{|c|}{$\begin{array}{l}\text { (1) P3 - P1 } \\
\text { (Pure price) }\end{array}$}} & \multicolumn{2}{|c|}{ (2) P3V1 - P1V3 } & \multicolumn{2}{|c|}{ (3) P3V3-P1V1 } & \multicolumn{2}{|c|}{$(4)=(2)-(1)$} & \multicolumn{2}{|c|}{$(5)=(3)-(1)$} & \multicolumn{2}{|c|}{$(6)=(2)-(3)$} \\
\hline Strategies & & & (Early & stage) & (Late & tage) & (Early & Pure) & (Late - & Pure) & (Early & Late) \\
\hline $\mathrm{J} * \mathrm{~K}$ & Returns & t-stat & Returns & t-stat & Returns & t-stat & Returns & t-stat & Returns & t-stat & Returns & t-stat \\
\hline $6 * 3$ & -0.27 & $(-0.92$ & 0.11 & $(0.22)$ & -0.35 & $(-0.81)$ & 0.38 & $(0.86)$ & -0.09 & $(-0.2$ & 0.47 & $(0.62)$ \\
\hline $6 * 6$ & -0.01 & $(-0.04)$ & 0.26 & $(0.54)$ & -0.34 & $(-0.85)$ & 0.27 & $(0.66)$ & -0.33 & $(-0.97)$ & 0.60 & $(0.84)$ \\
\hline $6 * 9$ & 0.18 & $(0.82)$ & 0.60 & $(1.31)$ & -0.12 & $(-0.31)$ & 0.41 & $(1.02)$ & -0.30 & $(-0.91)$ & 0.72 & $(1.00)$ \\
\hline $6 * 12$ & 0.09 & $(0.45)$ & 0.53 & $(1.21)$ & -0.22 & $(-0.58)$ & 0.43 & $(1.08)$ & -0.31 & $(-0.97)$ & 0.74 & $(1.07)$ \\
\hline
\end{tabular}

\subsection{Profitability in the Long Term}

In this subsection, I investigated long-term performance of volume-based price momentum investment. Panel A of Table 3 documented returns on hedge portfolios over each of the five event years, whereas Panel B reported cumulative performance over the five-year holding period. Results in Panel A basically confirmed the results in Table 2 , in that the volume-based early-stage investment outperformed pure price momentum investment in terms of economic magnitude and, conversely, the late-stage strategies underperformed. Besides, the early-stage strategies systematically generated higher returns than the late-stage strategies. More importantly, Panel A showed that the return difference in most event years lacks statistical significance but Panel B documented that the accumulated return difference becomes strong enough to generate statistical significance starting around the third year onwards. Figure 1 depicted the accumulated return dynamics of the three investment strategies over the five-year horizons.

It is worth mentioning that the emergence of statistical strength only in terms of long horizons may be associated with the absence of intermediate-term pure price momentum in this market revealed by prior research. The exclusive long-run phenomenon is inconsistent with the US evidence, which showed volume-related differential performance in both intermediate and long terms (Lee and Swaminathan, 2000). The differential empirical evidence in the two markets may be rooted in the prior findings of strong intermediate-term price momentum in the US versus weak price momentum in Taiwan, which is a signal of weak intermediate-term effects in Taiwan. 
Table 3. Returns on hedge portfolios over event years

\begin{tabular}{|c|c|c|c|c|c|c|c|c|c|c|}
\hline \multirow{2}{*}{\multicolumn{2}{|c|}{\begin{tabular}{|c|c|} 
Strategies & Equations \\
Panel A: Returns by event year
\end{tabular}}} & \multirow{3}{*}{$\begin{array}{c}\mathrm{R}(1 \mathrm{st}-\mathrm{Yr}) \\
\\
0.75\end{array}$} & \multicolumn{2}{|c|}{$\mathrm{R}(2 \mathrm{nd}-\mathrm{Yr})$} & \multicolumn{2}{|c|}{$\mathrm{R}(3 \mathrm{rd}-\mathrm{Yr})$} & \multicolumn{2}{|c|}{$\mathrm{R}(4 \mathrm{th}-\mathrm{Yr})$} & \multicolumn{2}{|c|}{$\mathrm{R}(5 \mathrm{th}-\mathrm{Yr})$} \\
\hline & & & & & & & & & & \\
\hline \multirow[t]{2}{*}{ Pure Price } & P3 - P1 & & -5.07 & **** & 1.82 & & -2.56 & & -1.02 & \\
\hline & & $(0.49)$ & $(-2.67)$ & & $(1.50)$ & & $(-1.59)$ & & $(-0.51)$ & \\
\hline \multirow[t]{2}{*}{ Early Stage } & P3V1 - P1V3 & 4.56 & -1.69 & & 8.63 & ** & 1.59 & & 1.49 & \\
\hline & & $(1.27)$ & $(-0.43)$ & & $(2.56)$ & & $(0.47)$ & & $(0.38)$ & \\
\hline \multirow[t]{2}{*}{ Late Stage } & P3V3 - P1V1 & -2.85 & -7.93 & $* *$ & -2.84 & & -4.76 & $*$ & -3.45 & \\
\hline & & $(-0.98)$ & $(-2.59)$ & & $(-1.06)$ & & $(-1.97)$ & & $(-1.17)$ & \\
\hline \multirow[t]{2}{*}{ Early - Pure } & (P3V1 - P1V3) - (P3 - P1) & 3.82 & 3.38 & & 6.80 & ** & 4.15 & & 2.51 & \\
\hline & & $(1.27)$ & $(1.05)$ & & $(2.34)$ & & $(1.62)$ & & $(0.89)$ & \\
\hline \multirow[t]{2}{*}{ Late - Pure } & (P3V3 - P1V1) - (P3 - P1) & -3.59 & -2.86 & & -4.66 & * & -2.19 & & -2.43 & \\
\hline & & $(-1.18)$ & $(-0.86)$ & & $(-1.75)$ & & $(-0.85)$ & & $(-0.81)$ & \\
\hline \multirow[t]{2}{*}{ Early - Late } & (P3V1 - P1V3) - (P3V3 - P1V1) & 7.41 & 6.24 & & 11.46 & ** & 6.35 & & 4.94 & \\
\hline & & $(1.28)$ & $(1.02)$ & & $(2.20)$ & & $(1.30)$ & & $(0.91)$ & \\
\hline \multicolumn{2}{|c|}{ Panel B: Cumulative returns } & CR(1-Yr) & $\mathrm{CR}(2-\mathrm{Y}$ & & $\mathrm{CR}(3-$ & $\overline{\mathrm{Yr})}$ & $\mathrm{CR}(4-$ & Yr) & $\mathrm{CR}(5-$ & Yr) \\
\hline \multirow[t]{2}{*}{ Pure Price } & P3 - P1 & 0.75 & -4.32 & & -2.50 & & -5.06 & & -6.07 & \\
\hline & & $(0.49)$ & $(-1.64)$ & & $(-0.79)$ & & $(-1.38)$ & & $(-1.58)$ & \\
\hline \multirow[t]{2}{*}{ Early Stage } & P3V1 - P1V3 & 4.56 & 2.88 & & 11.51 & & 13.10 & & 14.59 & \\
\hline & & $(1.27)$ & $(0.49)$ & & $(1.55)$ & & $(1.49)$ & & $(1.55)$ & \\
\hline \multirow[t]{2}{*}{ Late Stage } & P3V3 - P1V1 & -2.85 & -10.77 & ** & -13.61 & ** & -18.37 & *** & -21.81 & *** \\
\hline & & $(-0.98)$ & $(-2.26)$ & & $(-2.37)$ & & $(-2.77)$ & & $(-2.70)$ & \\
\hline \multirow[t]{2}{*}{ Early-Pure } & (P3V1 - P1V3) - (P3 - P1) & 3.82 & 7.20 & & 14.00 & ** & 18.16 & $* *$ & 20.66 & $* * *$ \\
\hline & & $(1.27)$ & $(1.51)$ & & $(2.31)$ & & $(2.55)$ & & (2.61) & \\
\hline \multirow[t]{2}{*}{ Late - Pure } & (P3V3 - P1V1) - (P3 - P1) & -3.59 & -6.45 & & -11.11 & * & -13.31 & $*$ & -15.74 & $*$ \\
\hline & & $(-1.18)$ & $(-1.24)$ & & $(-1.80)$ & & $(-1.89)$ & & $(-1.89)$ & \\
\hline \multirow[t]{2}{*}{ Early - Late } & (P3V1 - P1V3) - (P3V3 - P1V1) & 7.41 & 13.65 & & 25.12 & ** & 31.46 & $* *$ & 36.40 & $* *$ \\
\hline & & $(1.28)$ & (1.44) & & $(2.15)$ & & $(2.32)$ & & $(2.35)$ & \\
\hline
\end{tabular}

$* * *, * *$, and $*$ denote significant levels of $1 \%, 5 \%$, and $10 \%$, respectively.

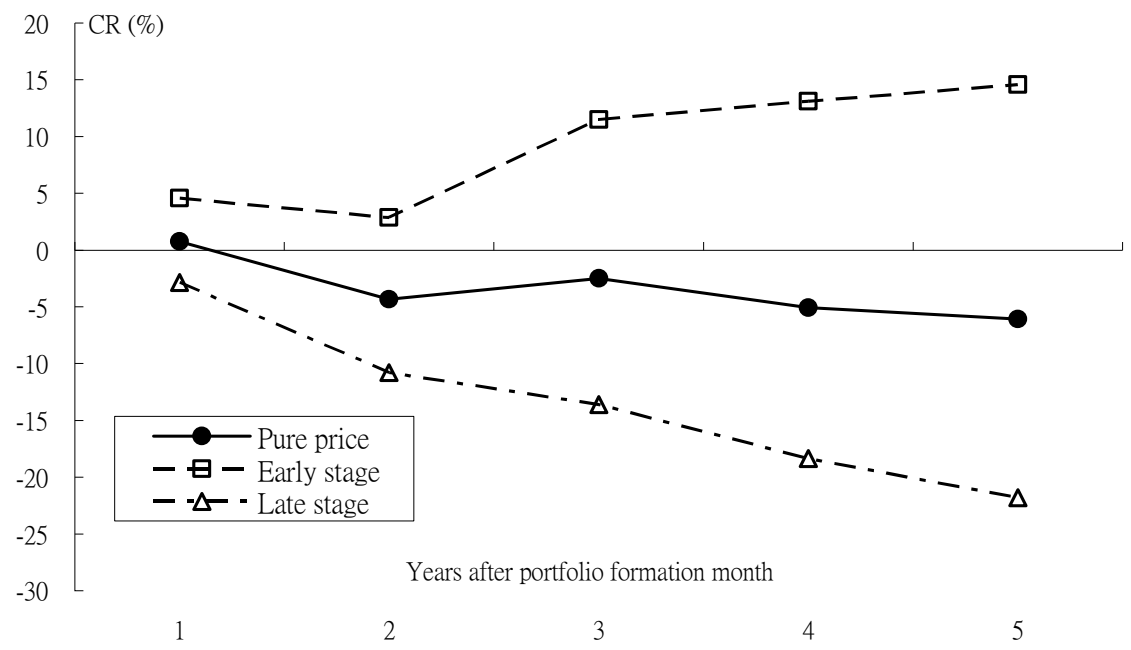

Figure 1. Cumulative raw returns on hedge portfolios for various price momentum strategies

\subsection{Adjusted Profitability in the Long Term}

I further addressed the issue whether profitability of the volume-based price momentum strategies is robust to control variables of industry effects, book-to-market-ratio and firm size. The reason to choose these factors is that they have been empirically confirmed to be associated with price momentum and/or trading volume phenomena. In particular, Moskowitz and Grinblatt (1999) reported dissipation of price momentum profits after controlling for industry effects, although Grundy and Martin (2001) discovered contrary evidence of persistence of momentum returns conditioned on industry effects. Lee and Swaminathan (2000) reported trading volume as a proxy for distinguishing between value and glamour stocks, as mentioned previously. Among others, book-to-market ratio is a common factor in defining value versus glamour stocks. In Table 1 of this study, firm size seems to be larger for low-volume stocks, as mentioned previously. 
In accordance with the two-digit industry codes developed by TWSE, I used 18 industries to construct value-weighted industry benchmark portfolios, estimating industry-adjusted returns on individual stocks by subtracting related industry benchmark portfolio returns from raw returns of individual stocks. (Note 2) As in the research by Chui et al. (2003), I built book-to-market or firm-size benchmark portfolios by using breakpoints of 30\% (bottom), 40\% (medium), and 30\% (top) to categorise stocks into three subgroups, and estimated benchmark portfolio returns for each BM or size portfolio. Following the approach developed by Fama and French (1996), I used the book value and market capitalisation at the end of the prior year to estimate book-to-market ratio for this-year July to next-year June. I computed firm size and built firm-size benchmark portfolios for each month. It is worth noting that the sample in this subsection is smaller than that used in the previous subsections in terms of both the number of firms and the time horizon covered due to two reasons. First, many de-listed stocks do not have full range of available data for early years, especially book values. Therefore, they are omitted for these periods. Secondly, certain early periods are truncated due to lack of enough firms in building nine volume-based price momentum portfolios. (Note 3) Taken together, the sample period in this subsection ranges from 1982 to 2003.

Results for adjusted cumulative returns in Table 4, in general, confirmed the results for raw returns in Table 3. In other words, the volume-based price momentum effects can be explained by none of the three control variables. It is worth mentioning that as compared to industry effects and book-to-market ratio, firm size seems to subsume the volume-based price momentum effects more intensively. The reason is that cumulative differential returns (relative to the three pairs of strategies) conditional on firm size at the end of year five is smaller in absolute economic magnitude than those conditional on industry effects or book-to-market ratio (see the last column for the last six rows in Panels A, B and C).

Table 4. Cumulative adjusted returns on hedge portfolios

\begin{tabular}{|c|c|c|c|c|c|c|c|c|c|c|c|}
\hline Strategies & Equations & CAR(1 & -Yr) & $\mathrm{CAR}(2$ & - -Yr) & $\mathrm{CAR}(3$ & - -Yr) & $\mathrm{CAR}(4$ & -Yr) & $\mathrm{CAR}(5$ & -Yr) \\
\hline Panel A: Indus & justed returns & & & & & & & & & & \\
\hline Pure Price & P3 - P1 & 0.20 & & -2.86 & & -3.94 & & -6.62 & $* *$ & -8.73 & $* * *$ \\
\hline & & $(0.15)$ & & $(-1.30)$ & & $(-1.63)$ & & $(-2.44)$ & & $(-3.20)$ & \\
\hline Early Stage & P3V1 - P1V3 & 5.21 & $*$ & 6.87 & & 9.09 & & 8.77 & & 6.56 & \\
\hline & & $(1.80)$ & & $(1.45)$ & & $(1.60)$ & & $(1.43)$ & & $(1.06)$ & \\
\hline Late Stage & P3V3 - P1V1 & -4.41 & $*$ & -12.86 & $* * *$ & -16.53 & $* * *$ & -19.56 & $* * *$ & -22.65 & $* * *$ \\
\hline & & $(-1.70)$ & & $(-2.92)$ & & $(-3.46)$ & & $(-3.97)$ & & $(-3.92)$ & \\
\hline Early - Pure & $(\mathrm{P} 3 \mathrm{~V} 1-\mathrm{P} 1 \mathrm{~V} 3)-(\mathrm{P} 3-\mathrm{P} 1)$ & 5.01 & $* *$ & 9.74 & $* *$ & 13.02 & $* * *$ & 15.38 & $* * *$ & 15.28 & $* * *$ \\
\hline & & $(2.03)$ & & $(2.58)$ & & $(2.98)$ & & $(3.19)$ & & $(3.00)$ & \\
\hline Late - Pure & $(\mathrm{P} 3 \mathrm{~V} 3-\mathrm{P} 1 \mathrm{~V} 1)-(\mathrm{P} 3-\mathrm{P} 1)$ & -4.61 & $*$ & -10.00 & $* *$ & -12.60 & $* *$ & -12.95 & $* *$ & -13.93 & $* *$ \\
\hline & & $(-1.90)$ & & $(-2.12)$ & & $(-2.40)$ & & $(-2.37)$ & & $(-2.25)$ & \\
\hline Early - Late & $(\mathrm{P} 3 \mathrm{~V} 1-\mathrm{P} 1 \mathrm{~V} 3)-(\mathrm{P} 3 \mathrm{~V} 3-\mathrm{P} 1 \mathrm{~V} 1)$ & 9.62 & $* *$ & 19.73 & $* *$ & 25.62 & $* * *$ & 28.33 & $* * *$ & 29.21 & $* * *$ \\
\hline & & $(2.10)$ & & $(2.49)$ & & $(2.82)$ & & $(2.96)$ & & $(2.78)$ & \\
\hline Panel B: BM a & ed returns & & & & & & & & & & \\
\hline Pure Price & P3 - P1 & -1.89 & & -7.68 & $* * *$ & -8.77 & $* * *$ & -12.40 & $* * *$ & -14.31 & $* * *$ \\
\hline & & $(-1.19)$ & & $(-2.93)$ & & $(-2.95)$ & & $(-3.63)$ & & $(-4.38)$ & \\
\hline Early Stage & P3V1 - P1V3 & -1.98 & & -5.68 & & -2.43 & & -0.90 & & 0.01 & \\
\hline & & $(-0.65)$ & & $(-1.25)$ & & $(-0.45)$ & & $(-0.16)$ & & $(0.00)$ & \\
\hline Late Stage & P3V3 - P1V1 & -2.64 & & -12.79 & $* * *$ & -17.08 & $* * *$ & -24.24 & $* * *$ & -30.65 & $* * *$ \\
\hline & & $(-0.82)$ & & $(-2.59)$ & & $(-2.94)$ & & $(-3.52)$ & & $(-4.75)$ & \\
\hline Early - Pure & $(\mathrm{P} 3 \mathrm{~V} 1-\mathrm{P} 1 \mathrm{~V} 3)-(\mathrm{P} 3-\mathrm{P} 1)$ & -0.09 & & 2.00 & & 6.34 & & 11.50 & $* *$ & 14.32 & $* *$ \\
\hline & & $(-0.03)$ & & $(0.45)$ & & $(1.19)$ & & $(2.01)$ & & $(2.34)$ & \\
\hline Late-Pure & $(\mathrm{P} 3 \mathrm{~V} 3-\mathrm{P} 1 \mathrm{~V} 1)-(\mathrm{P} 3-\mathrm{P} 1)$ & -0.75 & & -5.11 & & -8.31 & $*$ & -11.85 & $* *$ & -16.38 & $* * *$ \\
\hline & & $(-0.26)$ & & $(-1.16)$ & & $(-1.69)$ & & $(-2.20)$ & & $(-2.94)$ & \\
\hline Early - Late & $(\mathrm{P} 3 \mathrm{~V} 1-\mathrm{P} 1 \mathrm{~V} 3)-(\mathrm{P} 3 \mathrm{~V} 3-\mathrm{P} 1 \mathrm{~V} 1)$ & 0.65 & & 7.11 & & 14.65 & & 23.34 & $* *$ & 30.64 & $* * *$ \\
\hline & & $(0.12)$ & & $(0.87)$ & & $(1.52)$ & & $(2.25)$ & & $(2.86)$ & \\
\hline Panel C: Size a & d returns & & & & & & & & & & \\
\hline Pure price & P3 - P1 & 0.06 & & -3.04 & & -2.21 & & -4.37 & & -3.26 & \\
\hline & & $(0.04)$ & & $(-1.53)$ & & $(-0.88)$ & & $(-1.52)$ & & $(-0.97)$ & \\
\hline Early stage & P3V1 - P1V3 & 3.98 & $*$ & 2.02 & & 5.87 & & 5.04 & & 5.62 & \\
\hline & & $(1.82)$ & & $(0.55)$ & & $(1.39)$ & & $(0.97)$ & & $(1.06)$ & \\
\hline Late stage & P3V3 - P1V1 & -3.24 & & -8.62 & $* *$ & -8.66 & $*$ & -8.70 & $*$ & -8.95 & \\
\hline & & $(-1.34)$ & & $(-2.24)$ & & $(-1.96)$ & & $(-1.80)$ & & $(-1.48)$ & \\
\hline Early - Pure & $(\mathrm{P} 3 \mathrm{~V} 1-\mathrm{P} 1 \mathrm{~V} 3)-(\mathrm{P} 3-\mathrm{P} 1)$ & 3.93 & $* *$ & 5.05 & $*$ & 8.08 & $* *$ & 9.41 & $* *$ & 8.88 & $* *$ \\
\hline & & $(2.06)$ & & $(1.65)$ & & $(2.44)$ & & $(2.40)$ & & $(2.21)$ & \\
\hline Late - Pure & $(\mathrm{P} 3 \mathrm{~V} 3-\mathrm{P} 1 \mathrm{~V} 1)-(\mathrm{P} 3-\mathrm{P} 1)$ & -3.30 & $*$ & -5.58 & * & -6.45 & $*$ & -4.33 & & -5.70 & \\
\hline & & $(-1.77)$ & & $(-1.72)$ & & $(-1.80)$ & & $(-1.13)$ & & $(-1.22)$ & \\
\hline Early - Late & $(\mathrm{P} 3 \mathrm{~V} 1-\mathrm{P} 1 \mathrm{~V} 3)-(\mathrm{P} 3 \mathrm{~V} 3-\mathrm{P} 1 \mathrm{~V} 1)$ & 7.22 & $* *$ & 10.63 & * & 14.53 & $* *$ & 13.74 & $* *$ & 14.58 & $*$ \\
\hline & & $(2.11)$ & & $(1.87)$ & & $(2.35)$ & & $(1.98)$ & & $(1.87)$ & \\
\hline
\end{tabular}

$* * *, * *$, and $*$ denote significant levels of $1 \%, 5 \%$, and $10 \%$, respectively. 


\section{Conclusions}

Prior empirical evidence generally found an absence of price momentum in the Taiwanese stock market. Adding trading volume to the pure price momentum strategies, this study significantly improved the profitability of prior price momentum investment, consistent with the US evidence. However, the outperformance only occurs in long term and not in intermediate term. Specifically, volume-plus-price hedge portfolios of purchasing low-volume winners and selling high-volume losers-namely, the early-stage strategies-produced significantly higher cumulative returns during the period of 3-5 years after portfolio formation than pure price hedge portfolios of buying winners and selling losers. Over the similar long-term horizons, zero-cost investment strategies of holding long positions in high-volume winners and short positions in low-volume losers (that, the late-stage strategies), conversely, underperformed pure price momentum strategies. The asymmetry indicates continuation (reversal) of stock price dynamics among stocks relative to the early- (late-)stage strategies. The results are robust to adjustments of industry effects, firm size and book-to-market ratio. It is worth mentioning that firm size seems to subsume a larger portion of the volume-based price momentum phenomena than the other two adjustment variables because the economic magnitude of cumulative differential returns among the different strategies deteriorated more intensively conditional on firm size.

Note that the mainly long-term Taiwanese evidence is different from the US evidence because in the US, superior/inferior returns on volume-based price momentum strategies relative to pure price momentum strategies occurred in both intermediate and long terms. The underlying reason for the time-horizon difference may be that prior intermediate-term price momentum evidence is generally weak in Taiwan but strong in the US, which implies weak intermediate-term effects in Taiwan. Among others, one limitation of this study is the restriction of sample years. Investigation of more recent years warrants future research.

\section{References}

Amihud, Y., \& Mendelson, H. (1986). Asset pricing and the bid-ask spread. Journal of Financial Economics, 17, 223-249. http://dx.doi.org/10.1016/0304-405X(86)90065-6

Blume, M. (1974). Unbiased estimators of long-term expected rates of return. Journal of the American Statistical Association, 69(347), 634-638. http://dx.doi.org/10.1080/01621459.1974.10480180

Campbell, J. (1993). Intertemporal asset pricing without consumption data. American Economic Review, 83, 487-512.

Campbell, J., Grossman, S., \& Wang, J. (1993). Trading volume and serial correlation in stock returns. Quarterly Journal of Economics, 108(4), 905-939. http://dx.doi.org/10.2307/2118454

Chan, L., Jegadeesh, N., \& Lakonishok, J. (1996). Momentum strategies. Journal of Finance, 51(5), 1681-1713. http://dx.doi.org/10.1111/j.1540-6261.1996.tb05222.x

Chan, L., Jegadeesh, N., \& Lakonishok, J. (1999). The profitability of momentum strategies. Financial Analysts Journal (November-December), 80-90. http://dx.doi.org/10.2469/faj.v55.n6.2315

Chui, A., Titman, S., \& Wei, J. (2003). Momentum, legal systems and ownership structure: an analysis of Asian stock markets. Unpublished working paper. University of Texas at Austin.

Conrad, J., Hameed, A., \& Niden, C. (1994). Volume and autocovariances in short-horizon individual security returns. Journal of Finance, 49(4), 1305-1330. http://dx.doi.org/10.1111/j.1540-6261.1994.tb02455.x

Datar, V., Naik, N., \& Rodcliffe, R. (1998). Liquidity and stock returns: an alternative test. Journal of Financial Markets, 1, 203-219.

De Bondt, W., \& Thaler, R. (1985). Does the stock market overreact? Journal of Finance, 40(3), 793-805.

Ding, D.K., McInish, T.H., \& Wongchoti, U. (2008). Behavioral explanations of trading volume and short-horizon price patterns: An investigation of seven Asia-Pacific markets. Pacific Basin Finance Journal, 16(3), 183-203. http://dx.doi.org/10.1016/j.pacfin.2007.01.002

Duffee, G. (1992). Trading volume and return reversals. Finance and Economics Discussion Paper Series No. 192. Board of Governors of the Federal Reserve System.

Fama, F., \& French, K. (1996). Multifactor explanation of asset pricing anomalies. Journal of Finance, 51(1), 55-84. http://dx.doi.org/10.1111/j.1540-6261.1996.tb05202.x

Fu, H.-P., \& Wood, A. (2010). Momentum profits in Taiwan: Seasonality matters! Applied Economics Letters, 17(13), 
1247-1253.

Gallant, R., Rossi, P., \& Tauchen, G. (1992). Stock prices and volume. Review of Financial Studies, 5(2), 199-242. http://dx.doi.org/10.1093/rfs/5.2.199

Griffin, J., X. Ji, \& Martin, S. (2005). Global momentum strategies: a portfolio perspective. Journal of Portfolio Management, 31, 23-39. http://dx.doi.org/10.3905/jpm.2005.470576

Grundy, B., \& Martin, J. (2001). Understanding the nature of the risks and the source of the rewards to momentum investing. Review of Financial studies, 14, 29-78. http://dx.doi.org/10.1093/rfs/14.1.29

Hameed, A., \& Kusnadi, Y. (2002). Momentum strategies: evidence from the pacific basin stock markets. Journal of Financial Research, 25, 387-397.

Hong, H., \& Yu, J. (2004). Gone fishin': seasonality in speculative trading and asset prices. Journal of Financial Markets, 12(4), 672-702. http://dx.doi.org/10.1016/j.finmar.2009.06.001

Jegadeesh, N. (1990). Evidence of predictable behavior of security returns. Journal of Finance, 45(3), 881-898. http://dx.doi.org/10.1111/j.1540-6261.1990.tb05110.x

Jegadeesh, N., \& Titman, S. (1993). Returns to buying winners and selling losers: implications for stock market efficiency. Journal of Finance, 48(1), 65-91. http://dx.doi.org/10.1111/j.1540-6261.1993.tb04702.x

Jegadeesh, N., \& Titman, S. (2001). Profitability of momentum strategies: An evaluation of alternative explanations. Journal of Finance, 56(2), 699-720. http://dx.doi.org/10.1111/0022-1082.00342

Lee, C., \& Swaminathan, B. (2000). Price momentum and trading volume. Journal of Finance, 55(5), 2017-2069. http://dx.doi.org/10.1111/0022-1082.00280

Lehmann, B. (1990). Fads, martingales and market efficiency. Quarterly Journal of Economics, 105, 1-28. http://dx.doi.org/10.2307/2937816

Llorente, G., Michaely, R., Saar, G., \& Wang, J. (2001). Dynamic volume-return relation of individual stocks. Working paper 8312. National Bureau of Economic Research.

Morse, D. (1980). Asymmetric information in securities markets and trading volume. Journal of Financial and Quantitative Analysis, 15(5), 1129-1148. http://dx.doi.org/10.2307/2330176

Moskowitz, T., \& Grinblatt, M. (1999). Do industries explain momentum? Journal of Finance, 54(4), 1249-1290.

Shawn, L.K.J., Dawei, D.L., \& Benjamin, P.Z.E. (2013). Testing the profitability of a volume-augmented momentum strategy in the Philippines equity market. Journal of Applied Finance and Banking, 3(1), 1-12.

\section{Notes}

Note 1. A stock de-listed during a holding period is excluded starting from the de-listing month onwards. Negative one hundred percent is assigned to the return of the final month (for similar treatment, see De Bondt \& Thaler, 1985, footnote 4, p. 798).

Note 2. The 18 industries are (industry codes are in parenthesis): cement (11), foods (12), plastics (13), textiles (14), electricity and machinery (15), electricity appliance and cable (16), chemicals (17), glass and ceramics (18), paper and pulp (19), steel and iron (20), rubber (21), automobile (22), electronics (23), construction (25), transportation (26), tourism (27), wholesale, retail and conglomerate $(29,98)$ and others (99).

Note 3. Recall that a portfolio must have at least five component stocks (see discussion in Section 2). 